\title{
The Role of The UN Security Council vis- À-Vis The International Criminal CoUrt - RESOLUTION 1970 (2011) AND ITS CHALLENGES to International Criminal Justice
}

\author{
Gabriel M. Lentner ${ }^{1}$ \\ Danube University Krems, Austria \\ email: gabriel.lentner@donau-uni.ac.at
}

LENTNER, Gabriel M. The Role of the UN Security Council vis-à-vis the International Criminal Court - Resolution 1970 (2011) and its challenges to International Criminal Justice. International and Comparative Law Review, 2014, Vol. 14., No. 2, pp. 7-23. DOI: 10.1515/iclr-2016-0048.

\begin{abstract}
On February 26 2011, the UN Security Council unanimously adopted Resolution 1970 referring the situation concerning Libya to the International Criminal Court (ICC). This unprecedented support for and acknowledgment of the ICC did not come without a price: conditio sine qua non for Council members not party to the ICC was the inclusion of operative $\$ 6$ into the resolution, which exempts certain categories of nationals of non-parties from ICC jurisdiction. The same highly controversial exemption was included in the Security Council's referral of the situation in Darfur to the ICC in 2005.

Deviating from the Rome Statute's jurisdiction regime such practice not just poses challenges to principles of international criminal justice but raises the question whether the Rome Statute is altered by the resolution containing the referral to the effect that the ICC is being bound to the exemptions contained in its exercise of jurisdiction.

Addressing these issues, the present paper elaborates firstly on the jurisdictional exemption of $\$ 6$ and its effect on the ICC, followed by a discussion of resulting challenges to the principle of legality, the principle of universal jurisdiction for international crimes, the equality of individuals before the law and the principle of independence of the court.
\end{abstract}

Keywords: UN Security Council; referral; International Criminal Court; international criminal justice; Resolution 1970

\section{Introduction}

On February 26 2011, the United Nations Security Council (SC) unanimously adopted Resolution $1970^{2}$ referring the situation of Libya to the International

1 Gabriel M. Lentner, Mag.iur., is Research and Teaching Fellow at the Danube University Krems and $\mathrm{PhD}$ Candidate at the University of Vienna.

2 UNSC Res 1970 (26 February 2011) UN Doc S/RES/1970 [hereinafter Resolution 1970]; for the relevant parts see below. 
Criminal Court (ICC) pursuant to art $13(\mathrm{~b})^{3}$ of the Rome Statute ${ }^{4}$. As in its first referral to the ICC (Resolution 1593) ${ }^{5}$, Resolution 1970 includes operative $₫ 6$ which exempts jurisdiction of the court for certain categories of nationals of non-parties to the Rome Statute and puts them under the exclusive jurisdiction of their state of nationality. ${ }^{6}$ It was dominantly the US, which pushed for such language. ${ }^{7}$ Additionally, both resolutions imposed cooperation obligations only upon the respective state at issue (Sudan and Libya). ${ }^{8}$

Deviating from the provisions of the Rome Statute, such 'exclusive jurisdiction' resulted in heavy criticism following the adoption of resolution 1593 (2005) expressed by State representatives ${ }^{9}$, and commentators ${ }^{10}$ alike, questioning its legality under international law. ${ }^{11}$

Interestingly, even though identically worded in this respect, almost no criticism was voiced in the aftermath of resolution 1970 (2011). ${ }^{12}$ It was even praised as "a historic moment in accountability for crimes under international law". ${ }^{13}$

A closer look however, reveals the fact that resolution 1970 challenges important principles of international criminal justice.

3 Which reads "The Court may exercise its jurisdiction with respect to a crime referred to in article 5 in accordance with the provisions of this Statute if: (b) A situation in which one or more of such crimes appears to have been committed is referred to the Prosecutor by the Security Council acting under Chapter VII of the Charter of the United Nations;"

4 Rome Statute establishing the International Criminal Court 2187 UNTS 38544.

5 UNSC Res 1593 (31 March 2005) UN Doc S/RES/1593 [hereinafter Resolution 1593]; This resolution concerned the situation in Darfur.

6 These are "current or former officials or personnel from a State outside the Libyan Arab Jamahiriya which is not a party to the Rome Statute of the International Criminal Court [...] for all alleged acts or omissions arising out of or related to operations in the Libyan Arab Jamahiriya established or authorized by the Council".

7 Jennifer Trahan, 'The Relationship Between the International Criminal Court and the U.N. Security Council: Parameters and Best Practices' (2013) 24(4) Crim Law Forum 417, 454.

8 ibid 449.

9 UNSC Verbatim Record (31 March 2005) UN Doc S/PV.5158; see especially statements of Brazil, Benin, Tanzania, Greece, France, Argentina, Denmark.

10 See eg: Luigi Condorelli and Annalisa Ciampi, 'Comments on the Security Council Referral of the Situation in Darfur to the ICC' (2005) 3(3) Journal of International Criminal Justice, 590; Robert Cryer, 'Sudan, Resolution 1593, and International Criminal Justice' (2006) 19(1) Leiden Journal of International Law, 195; Matthew Happold, 'II. Darfur, the Security Council, and the International Criminal Court', (2006) 55(1) International \& Comparative Law Quarterly, 226.

11 For a comprehensive account of the main issues raised see eg: $i b i d$.

12 See Statement by the Brazilian Representative: Verbatim Record (26 February 2011) UN Doc S/PV.6491, 7.

13 See eg. Amnesty International, 'Unanimous Security Council vote a crucial moment for international justice' (27 February 27 2011) <www.amnesty.org/en/news-and-updates/ unanimous-security-council-vote-crucial-moment-international-justice-2011-02-28>

\section{(c) Palacký University Olomouc, Czech Republic, 2014. ISSN 1213-8770 (print), ISSN: 2464-6601 (online).}


In this paper the following issues are being addressed: the legal effect of $₫$ 6 for the ICC followed by the conceptualization of jurisdiction of the ICC in practice, and discussing challenges to: (3.1) the Principle of Legality, (3.2.) the Principle of Universal jurisdiction, (3.3), the Principle of Equality of Individuals before the Law, and (3.4) the principle of independence of the International Criminal Court.

\section{Jurisdictional Exemption of $\$ 6$ and the Rome Statute}

Acting under Chapter VII of the Charter of the United Nations (Charter), the UN Security Council referred the situation concerning Libya to the International Criminal Court with the following exemption. The exemption included in operative $\$ 6$ of resolution 1970 (2011) reads in the relevant part:

[The Security Council, acting under Chapter VII of the Charter of the United Nations,...] Decides that nationals, current or former officials or personnel from a State outside the Libyan Arab Jamahiriya which is not a party to the Rome Statute of the International Criminal Court shall be subject to the exclusive jurisdiction of that State for all alleged acts or omissions arising out of or related to operations in the Libyan Arab Jamahiriya established or authorized by the Council, unless such exclusive jurisdiction has been expressly waived by the State; $;^{14}$

The Rome Statute of the International Criminal Court regulates SC referrals in its art 13(b) which provides:

The Court may exercise its jurisdiction with respect to a crime referred to in article 5 in accordance with the provisions of this Statute if: [...] (b) A situation in which one or more of such crimes appears to have been committed is referred to the Prosecutor by the Security Council acting under Chapter VII of the Charter of the United Nations; [...]

The jurisdictional exemption quoted seems hard to reconcile with the jurisdiction regime provided in art 13(b) of the Rome Statute.

As is clear from the legal considerations during the negotiation of article 13, the wording was specifically chosen to avoid referring only individual cases. Art 13 refers to 'situations' a word which was intended to avoid political interference by a 'pick and choose' approach, as evidenced by the drafting history, during which the wording was changed from 'case' to 'matters' to 'situations. ${ }^{15}$ Indeed, also the Pre-Trial Chamber of the ICC has explained that this phrase means that

14 The exact same wording was included in $₫ 6$ of UNSC Res 1593 (n 4).

15 William A. Schabas, 'Article 13 Exercise of jurisdiction' in Otto Triffterer and Kai Ambos (eds), Commentary on the Rome Statute of the International Criminal Court: Observers' notes, article by article (2nd ed, C.H. Beck; Hart; Nomos 2008), para 13 
a referral cannot limit the Prosecutor to investigate eg only crimes committed by certain persons $\mathbf{s}^{16} \cdot{ }^{17}$

Thus, the exemption for certain categories of nationals from the Court's jurisdiction pursuant to $\$ 6$ of the resolution appears to be in conflict with the text of art 13(b) of the Statute. ${ }^{18}$

While extensive debates elaborated on the legality and effect of $\$ 6$ following the Darfur referral, Resolution 1970 raises further questions, not least due to its unanimous adoption and the lack of subsequent criticism. ${ }^{19}$ Such continued practice could point to developing acceptance or acquiescence of such troubling SC action. ${ }^{20}$

The following considerations apply to both Resolutions, and it is important to note that presently the impact of operative $\$ 6$ of Resolution was neither addressed by the Prosecutor, nor by the Chambers. ${ }^{21}$ The Prosecutor in his Third Report to the UN Security Council concerning the situation in Libya, however, asserted without further explanation that " $[\mathrm{t}]$ he Office does have a mandate, however, to investigate allegations of crimes by all actors" ${ }^{22}$ not mentioning $\$ 6$ of the relevant Resolution.

Such developments therefore merit a closer look at these issues.

\subsection{Security Council Referrals to the ICC}

Most authors arrive at the conclusion that $\$ 6$ leaves obligations of state parties to the ICC in conflict with their obligations under the UN Charter ${ }^{23} .{ }^{24}$ This

16 Prosecutor $v$ Callixe Mbarushimana (Decision on the Defence Challenge to the Jurisdiction of the Court) (26 October 2011) ICC_01/04-01/10-451.

17 Nouwen, Sahra M. H. Complementarity in the line of fire: The Catalysing Effect of the International Criminal Court in Uganda and Sudan (Cambridge studies in law and society, Cambridge University Press 2013) 87.

18 The Relationship Agreement concluded between the UN and the ICC is not insightful in that respect.

19 The so-called 'peacekeeping exemptions' should be recalled: see Resolutions 1422 (2002), 1487 (2003) 1497 (2003) a practice that was discontinued, while apparently serving as a role model for Resolutions 1593 and 1970.

20 Such practice is important since legal defects might be cured by operation of acquiescence or acceptance, see Jan Klabbers, An introduction to international institutional law (Cambridge University Press 2002) 241.

21 Carsten Stahn, 'How is the water? Light and Shadow in the first years of the ICC' (2011) 22 (1-2) Criminal Law Forum, 175, 179.

22 Prosecutor of the International Criminal Court, 'Third Report of the Prosecutor of the International Criminal Court to the UN Security Council pursuant to UNSCR 1970 (2011)' (16 May 2012) <http://www.icc-cpi.int/NR/rdonlyres/D313B617-6A86-4D6488AD-A89375C18FB9/0/UNSCreportLibyaMay2012Eng.pdf $>$ para 55.

23 To give effect to the decisions of the Security Council pursuant to Art 25 UN Charter.

24 Eg: Sebastian Heselhaus, 'Resolution 1422 (2002) des Sicherheitsrates zur Begrenzung der Tätigkeit des Internationalen Strafgerichtshof' (2002) 62 Zeitschrift für ausländisches 
is explained by the understanding that the Rome Statute does not allow for such exemptions and hence the obligation to respect the SC resolution referring such 'limited' jurisdiction is not reconcilable with the obligation of States party to the ICC to respect the provisions of the Rome Statute.

Furthermore, it is sometimes asserted that legally, the Security Council referral can only activate the Rome Statute as a whole, not select parts thereof. ${ }^{25}$ It is further assumed that these exemption clauses would not withstand judicial scrutiny in the court itself, which under art 19(1) RS shall satisfy itself that it has jurisdiction in any case brought before it. It is important that these and the underlying assumptions of any such legal conclusions must be carefully analysed. Before turning to the specifics of $₫ 6$, the preliminary question regarding the conception of criminal jurisdiction exercised by the ICC must be addressed however. Only after conceptualizing the jurisdiction regime provided for SC referrals we can turn to the question of its legal effects and challenges.

\subsection{Jurisdiction of the International Criminal Court}

Jurisdiction ${ }^{26}$ of the International Criminal Court ${ }^{27}$ is explained here on the basis of delegation of authority by states parties ${ }^{28} .{ }^{29}$ Under international law, it is within the sovereign right of a State to voluntarily designate an international court to exercise the jurisdiction over a crime committed on its territory by vir-

öffentliches Recht und Völkerrecht, 907, 910.

25 Global Policy Forum, 'The Relationship Between the ICC and the Security Council: Challenges and Opportunities' [2012] International Peace Institute <www.globalpolicy. org/international-justice/the-international-criminal-court/icc-in-the-securitycouncil6-4/52118-the-relationship-between-the-icc-and-the-security-councilchallenges-andopportunities.html>; see also D. Kaye, 'The Council and The Court: Improving Security Council Support of the International Criminal Court' (2013) Univ. of California School of Law, 6 <http://councilandcourt.org/files/2013/05/The-Council-and-the-Court-FINAL. pdf $>$; "Some observers believe that, if such a situation were presented to a chamber of the Court, the judges may ignore the exemption from investigation of citizens of non-state parties and apply the Rome Statute, assuming jurisdiction and admissibility requirements are met." Trahan (n 6) 457.

26 See generally on the meaning on 'jurisdiction' under international law, eg ILC, 'Preliminary report on immunity of State officials from foreign criminal jurisdiction' (5 May-6 June and 7 July-8 August 2008) UN Doc A/CN.4/601, para 44 [with further references].

27 Articles 12, 13(a), 14, 98 Rome Statute.

28 Dapo Akande, 'The jurisdiction of the international criminal court over nationals of nonParties: legal basis and limits' (2003) 1 Journal of International Criminal Justice, 618ff.

29 Michail Vagias, 'The Territorial Jurisdiction of the International Criminal Court - A Jurisdictional Rule of Reason for the ICC?' (2012) 59(1) Netherlands International Law Review, 43,44 . 
tue of a multilateral treaty. ${ }^{30}$ In such cases, jurisdiction of the ICC satisfies the classic logic of criminal justice and State sovereignty. ${ }^{31}$

It is a different issue, however, when jurisdiction of the ICC is not delegated by the respective State but finds its basis in a UN SC resolution referring a case to the ICC, which is the case regarding the situation in Libya and Resolution 1970 (2011).

While it is true that, by itself, the decision to confer jurisdiction to an international tribunal does not necessarily require the State concerned to do anything. Nevertheless, the State in question (here Libya) is legally bound (by virtue of the binding SC resolution under Chapter VII of the UN Charter) to accept that the ICC has jurisdiction in the circumstance in which the Security Council has conferred jurisdiction. ${ }^{32}$ It follows then, that SC referrals concerning non-State parties to the ICC, the basis of the jurisdictional authority of the ICC is solely the SC resolution. This in turn means, that the extent and scope of jurisdiction conferred is determined entirely by the SC resolution and cannot be limited nor extended by provisions of the Rome Statute.

The questions regarding the scope of jurisdiction ratione loci, ratione personae, ratione materiae, ratione temporis must therefore be answered with recourse to the resolution including the referral (ie resolution 1970) as well as (implicitly) considering potential (implied) limits to the SC acting under Chapter VII stemming from the Charter. ${ }^{33}$

Conceptually, this means that the referral allows the SC - within the framework of the limits of Chapter VII of the Charter of the United Nations- to free the ICC from those limitations which otherwise derive from the fact that the ICC is created by an international treaty. ${ }^{34}$ It cannot however, free the ICC from limita-

30 Claudia Fritsche, 'Security Council Resolution 1422: Peacekeeping and the International Criminal Court' in Jochen A Frowein (ed), Verhandeln für den Frieden: Negotiating for peace : liber amicorum Tono Eitel (Beiträge zum ausländischen öffentlichen Recht und Völkerrecht vol 162. Springer 2003) 111.

31 ibid.

32 Dapo Akande, 'The Legal Nature of Security Council Referrals to the ICC and its Impact on Al Bashir's Immunities' (2009) 7(2) Journal of International Criminal Justice 333, 341; mutatis mutandis see eg: Jochen A Frowein and Nico Krisch, 'Chapter VII. Action with respect to Threats to the Peace, Breaches of the Peace, and Acts of Aggression' in Bruno Simma and others (eds), The Charter of the United Nations, A Commentary (2nd edn. C. H. Beck 2002) 45.

33 This is supported by an early commentator who wrote: "[...] whenever a matter is referred to the future ICC by the SC, the ICC would then act within the framework and on the basis of the resolution granting jurisdiction." Andreas Zimmermann, 'The Creation of a Permanent International Criminal Court' in Jochen A Frowein, Rüdiger Wolfrum and Christiane Philipp (eds), Max Planck Yearbook of United Nations law (Kluwer Law International 1998) 216.

34 ibid.; a more recent study confirms this view: Pichon J, Internationaler Strafgerichtshof und Sicherheitsrat der Vereinten Nationen: Zur Rolle des Sicherheitsrats bei der Verfolgung 
tions which derive from peremtpory norms (jus cogens) or other rules which the $\mathrm{SC}$ is bound by when exercising Chapter VII powers.

On the other hand it is important to note that the ICC and its organs, as any other international organization, can only operate on the basis of its constituent treaty. ${ }^{35}$ It is important to distinguish this question from the conclusion above that the SC is not limited by provisions of the Rome Statute.

In fact, while the UN Charter indeed asserts direct authority to restrict or compel actions, not just of UN Member States but also other international organizations in the case of regional arrangements or agencies dealing with regional issues of peace and security pursuant to Chapter VIII (arts 52, 53), the Charter nowhere does purport to authorize other international organizations to perform acts beyond their constitutent documents. ${ }^{36}$ This is indeed very important to note for the following.

The ICC cannot be viewed as a ,specialized agency' within the UN system. ${ }^{37}$ This means that art 13(b) of the Rome Statute must be considered when answering the question whether this provision may be understood as making the SC referral powers of the SC operational for the Court. The view adopted here, follows a „Charter friendly“ interpretation (encouraged by the Principle of Systemic Integration ${ }^{38}$ and the Presumption of Compatibility ${ }^{39}$ to avoid a conflict and application of art 103 of the Charter ${ }^{40} .{ }^{41}$ With inserting Art 13 (b) into the Rome

völkerrechtlicher Verbrechen durch den IStGH (Beiträge zum ausländischen öffentlichen Recht und Völkerrecht, Veröffentlichungen des Max-Planck-Instituts für ausländisches öffentliches Recht und Völkerrecht vol 218, Max-Planck-Gesellschaft zur Förderung der Wissenschaften e.V 2011).

35 Kenneth S Gallant, 'The International Criminal Court in the System of States and International Organizations' (2003) 16(3) Leiden Journal of International Law 553, 570.

36 ibid.

37 ibid.

38 Codified in Article 31 (3) (c) Vienna Convention on the Law of Treaties; see further Paulus AL and Leiß J, 'Article 103' in Bruno Simma (ed), The charter of the United Nations: A commentary (3rd edn. Oxford University Press 2012), 17-18, concluding “[...]contradiction should only be assumed when norms stand in clear conflict with each other or in the case that the contradictory intent is clearly expressed", ibid with further references.

39 See Right of Passage Case (Portugal v India) (Merits) [1960] ICJ Rep 6, cited in ibid (n 37) $17-18$.

40 Ibid, 18.

41 Adopting the contrary opinion, ie that a referral is only binding on the ICC when strictly in accordance with the letter of the provisions of the Statute, one must still concede that UN member States would be obliged to act to this end in line with Arts 25, 48, 53 and 103 UN Charter prescribing that "it is up to the member States to ensure that the international organizations they are members of respect and carry out SC decisions." Frowein and Krisch (n 31) 42; „,Moreover, according to Art. 53 (1), the SC can also utilize regional organizations for enforcement action, and it might on this basis even create obligations for them. Because of Art. 43, however, the latter conclusion is restricted to non-military enforcement measures. "ibid; regarding the conflicting treaty obligations (ie Rome Statute 
Statute, it is argued that the drafters clearly intended to enable the organs of the Court to act on SC referrals, while at the same time leaving broad discretionary powers of the SC untouched ${ }^{42}{ }^{43}$

However, regardless of what view one adopts on this issue, it is clear from the theory of delegation of jurisdictional authority, that the SC merely delegates criminal jurisdiction over the situation to the court. Since this is the only source of jurisdictional authority for the ICC, it cannot exercise more than what is provided for in the resolution. ${ }^{44}$ The exact scope of the delegation of jurisdiction in question remains under the discretion of the SC, since the Court can only exercise such authority that is delegated to it.

As a result, the ICC is bound by the exemptions for certain categories of nationals as included in SC Resolution 1970 (2011)

Assuming that the SC acts within its powers, interpretation of the resolution including the referral must then be conducted in light of potential limits to the SC with respect to referrals. Prima facie however, these resolutions must be considered intra vires. ${ }^{45}$ This means that if the SC delegates a 'limited' authority the Court it cannot exercise more than that, regardless of the provisions of the Statute. ${ }^{46}$ The Relationship Agreement concluded between the UN and the ICC,

vs UN Charter) much has been asserted around Art 103, Michael Wood's recent analysis seems accurate see Michael Wood, 'The Law of Treaties and the UN Security Council: Some Reflections' in Enzo Cannizzaro (ed), The Law of Treaties Beyond the Vienna Convention (Oxford University Press 2011) 253.

42 Luigi Condorelli and Villalpano argue that personal exemptions are not contravening the Rome Statute see L. Condorelli and S.Villalpando, 'Referral and Deferral by the Security Council', in A. Cassese et al. (eds), The Rome Statute for an International Criminal Court: A Commentary (Oxford University Press 2002) 627, 633,

43 Adding that "On the other hand it did not intend in any way to add to or increase the powers of the Council as defined in the Charter, as distinct from making available to it the jurisdiction mechanism created by the statute." United Nations 'Report of the Commission to the General Assembly on the work of its forty-sixth Session' (2 May - 22 July 1994) in: Yearbook of the International Law Commission 1994 (1997) 2(2) 44. [Commentary (1)]

44 Nemo plus iuris transferre potest quam ipse habet, Corpus iuris civilis (D. 50, 17, 54).

45 As Sir Michael Wood eloquently put it: "Much of the writing about the Security Council by international lawyers has an air of unreality. It is based neither on the practice of states nor on the practice of the organs of the United Nations, nor yet on decisions of courts and tribunals. It reflects the authors' dogmatic reading of the text of the United Nations Charter, and often attempts, unrealistically, to apply domestic or 'European' constitutional principles to the field of international relations. It seems to be asserted that much that the Council has done since the end of the Cold War is ultra vires, beyond its powers under the Charter, or otherwise unlawful. This is not, of course, the case." Wood (n 40) 247.

46 Applying binding Chapter VII resolutions, even if they are incompatible with the Court's Statute presupposes that the Court, as a treaty-organ created by UN member States, is also subject to Art. 103 of the UN Charter. However, [... the better arguments seem to militate in favour of the view that inernational organizations founded by member States of the $\mathrm{UN}$, are also subject to SC resolutions, provided however they have been adopted in accordance with the Charter."Andreas Zimmermann, "Acting under Chapter VII (...)" 
does not change this, since the SC is not bound by treaty law. ${ }^{47}$ That this conclusion leads to serious challenges to principles of international criminal justice is addressed in the following section.

\section{Challenges to Principles of International Criminal Justice}

\subsection{Challenges to the Principle of Legality}

As enshrined in Article 15 of the International Covenant on Civil and Political Rights (ICCPR), the principle of legality to a large extent requires the formal approach adopted by the international criminal courts and tribunals with respect to sources of international law ${ }^{48} .{ }^{49}$

\section{Article 22 (1) of the Rome Statute itself provides for}

A person shall not be criminally responsible under this Statute unless the conduct in question constitutes, at the time it takes place, a crime within the jurisdiction of the Court.

According to international jurisdprudence, the principle of legality „,requires that the offence with which an accused is charged was sufficiently foreseeable and that the law providing for such liability was sufficiently accessible to the accused at the relevant time. ${ }^{\text {“50 }}$ It is sufficient for those acts to be crimes under

- Resolution 1422 and Possible Limits of the Powers of the Security Council' in Jochen A Frowein (ed), Verhandeln für den Frieden: Negotiating for peace : liber amicorum Tono Eitel (Beiträge zum ausländischen öffentlichen Recht und Völkerrecht vol 162. Springer 2003) 275.; for a different view see eg. Nouwen, Sahra M. H. (n 16) 87.

47 Jakob Pichon, Internationaler Strafgerichtshof und Sicherheitsrat der Vereinten Nationen: Zur Rolle des Sicherheitsrats bei der Verfolgung völkerrechtlicher Verbrechen durch den IStGH (Beiträge zum ausländischen öffentlichen Recht und Völkerrecht, Veröffentlichungen des Max-Planck-Instituts für ausländisches öffentliches Recht und Völkerrecht vol 218, Max-Planck-Gesellschaft zur Förderung der Wissenschaften e.V 2011) 97.

48 International Covenant on Civil and Political Rights (adopted 16 December 1966, entered into force 23 March 1976) 999 UNTS 171 (ICCPR); see, inter alia, Report of the SecretaryGeneral Pursuant to Paragraph 2 of Security Council Resolution 808 (3 May 1993) UN Doc S/25704, 34; see A. Zammit Borda, 'A Formal Approach to Article 38(1)(d) of the ICJ Statute from the Perspective of the International Criminal Courts and Tribunals' (2013) 24(2) European Journal of International Law 649, 650 for further references.

49 Article 7 ECHR; Article 15 (2) ICCPR; Article 11(2) of the Universal Declaration of Human Rights; Article 9 American Convention on Human Rights; Article 7(2) African Charter on Human and Peoples' Rights.

50 Prosecutor v. Milutinović et al (Decision on Motion Challenging Jurisdiction) ICTY-99-37AR72 (21 May 2003), para 38; see also S.W. v. United Kingdom, App no 20166/92 (ECtHR, 22 November 1995), paras 35-36[indicating that the term "law" in Article 7 of the ECHR "comprises written as well as unwritten law and implies qualitative requirements, notably those of accessibility and foreseeability."] 
international law ${ }^{51}$ which is applicable. ${ }^{52}$ "An assessment of the foreseeability and accessibility requirements integral to the principle of legality should take into account the particular nature of international law, including its reliance on unwritten custom. ${ }^{\text {" }} 3$

In case of resolution 1970 (2011) referring the situation concerning Libya to the ICC, the question is whether application of the elements of crimes contained in the Statute are to be considered retroactive application of crimes. Especially since the Rome Statute as a multilateral treaty, is creating law for the States parties to the treaty, it is difficult to see on what basis States outside of the treaty regime are bound by the definitions of international crimes included in the Statute.

In fact, academics and politicians alike refused to accept the International Law Commission's proposition not to define crimes in the proposed Statute of the permanent ICC at a very early stage. ${ }^{54}$ Rather it was referred to existing instruments, ${ }^{55}$ because,$[\mathrm{m}]$ any felt that prosecutions in the proposed Court would run afoul of the nullum crimen, nulla poena, sine lege principle if crimes were not sufficiently defined in advance. ${ }^{\text {"56 }}$

A similar problem arose with respect to the qualification of the Nuremberg Trials. While arguably a rather theoretical debate concerning the Nuremberg Trials whether the substantive criminal law applied during the Nuremberg Trialso matched customary international law, ${ }^{57}$ or only law among the parties to the London Agreement and the Nuremberg Charter, it is important in this regard. ${ }^{58}$

This distinction becomes practically relevant in the case of referrals since some elements of the Rome Statute crimes seem indeed to partly departing from

51 See eg: Prosecutor $v$ Kordić et al (Judgement) IT-95-14/2-A (17 December 2004), paras 41-42; Prosecutor v. Milutinović et al (Decision on Motion Challenging Jurisdiction) IT-9937-AR72 (21 May 2003), paras 38-42.

52 Kononov v. Latvia App no 36376/04 (ECtHR 24 July 2008), para. 114; Prosecutor v. Milutinović et al (Decision on Motion Challenging Jurisdiction) ICTY-99-37-AR72 (21 May 2003), paras 34-44.

53 ibid [31].

54 Leila N Sadat, The International Criminal Court and the transformation of international law: Justice for the new millennium (International and comparative criminal law series, Transnational Publishers 2002) 265-266. [with further references]

55 ibid.

56 ibid.

57 Gallant (n 34) 577.

58 See eg. Leila N. Sadat and S. R. Carden, 'The New International Criminal Court: An Uneasy Revolution' (2000) 88 Georgetown Law Journal 381, 423; Gallant (n 34) 577.

\section{(C) Palacký University Olomouc, Czech Republic, 2014.} ISSN 1213-8770 (print), ISSN: 2464-6601 (online). 
present customary international $\operatorname{law}^{59} .{ }^{60}$ In fact, it has been pointed out that "states with military forces that operate abroad will fear that soldiers and their commanders, including the highest political authorities responsible for military activities, will be dragged in front of an international court for war crimes prosecution and will, at a minimum, be inconvenienced and embarrassed. Indeed, because the definitions of international crimes are so vague, soldiers and officials might find themselves punished for activities that they consider legal and routine." 61

This ambiguity regarding the state of customary crimes under international law is further evidenced by the fact that the drafters viewed it necessary to include art 10 into the Statute, which states that „[n] othing in this Part [definition of crimes] shall be interpreted as limiting or prejudicing in any way existing or developing rules of international law for purposes other than this Statute." ${ }^{62}$ Here the ICC Statute disclaims an intent to define substantive international law, including substantive international criminal law, for anyone other than the international organization of the ICC itself. ${ }^{63}$

Specifically problematic is the fact that there is no international treaty defining crimes against humanity. The Preparatory Committee of the future ICC did not reach consensus regarding the exact definition of crimes against humanity. ${ }^{64}$ Hence, art 7, defining crimes against humanity, may thus be regarded as creating an autonomous regime. ${ }^{65}$

Another problematic issue concerns the Rome Statutes definition of war crimes, since the definitions regarding non-international armed conflict, appear to depart from accepted international custom. ${ }^{66}$

59 Regarding Crimes Against Humanity some elements appear to be new or different from existing sources, cf Herman von Hebel and Darryl Robinson, 'Crimes within the Jurisdiction of the Court' in Roy S Lee (ed), The International Criminal Court: The making of the Rome Statute ; issues, negotiations, results (Kluwer Law International 2002), 92; Roy S K Lee, 'States' Responses: Issues and Solutions' in Roy S K Lee (ed), States' responses to issues arising from the ICC statute: Constitutional, sovereignty, judicial cooperation and criminal law (International and comparative criminal law series. Transnational Publishers 2005) 26.

60 see also Jallow who sees considerable expansion of international criminal law particularly regarding crimes against humanity and war crimes Hassan B Jallow, 'International criminal justice: reflections on the past and the future' (2010) 36(2) Commonwealth Law Bulletin 269, 275.

61 Eric A Posner and John C Yoo, 'Judicial Independence in International Tribunals' (2005) 93(1-74) California Law Review, 69.

62 See also Article 22 (3) which states, regarding the principle of nullum crimen sine lege, "This article shall not affect the characterization of any conduct as criminal under international law independently of this Statute."

63 Gallant (n 34) 577.

64 Zimmermann, 'The Creation of a Permanent International Criminal Court' (n 32) 172.

65 Lee (n 58) 26.

66 An elaborate study of this issue is beyond the scope of this paper. 
It is clear however, that in cases where the State in question is bound to international treaties applicable, their application by the ICC does not pose issues of legality. The operation of such differences in the scope of jurisdiction ratione materae is ensured by art 10 (reference to customary international law) in connection with arts 21 (applicable law) and 19 (determination of jurisdiction) of the Rome Statute.

While it is beyond the scope of the present paper to analyse the state of crimes against humanity and war crimes under customary international law or whether the SC is even bound by the principle of legality with regards to international criminal law, ${ }^{67}$ it is important to raise this issue for the sake of the prominent place the principle of legality occupies in international criminal law. And to persuade the Chambers of the ICC to address this issue. It shall be noted in this respect that the SC itself implicitly found to be bound by the principle of legality when it insisted that when establishing the ad hoc tribunals, it did not create new law but was merely applying existing $\operatorname{law}^{68} .{ }^{69}$

As a result, in the case of resolution 1970 (2011) the ICC's jurisdiction is limited to adjudicate crimes recognized as part of customary international law. ${ }^{70}$

\subsection{Challenges to the Principle of Universal Jurisdiction}

Following the adoption of Resolution 1593 (2005) referring the situation concerning Darfur to the ICC, the representative for Denmark stated, referring to the exemption, that "the language on exclusive jurisdiction [...] does not affect the universal jurisdiction of Member States in areas such as war crimes, torture, and terrorism." ${ }^{71}$ Even the Canadian Prime Minister raised concerns asserting that such exemption was "inconsistent with basic legal principles of accountability [and that it] must not establish a precedent for future Security Council referrals to the International Criminal Court." ${ }^{72}$ Unfortunately, with adoption of Resolution 1970 such practice was in fact continued, only this time with unanimous support in the Security Council. ${ }^{73}$

67 For an affirmative view see eg. Pichon (n 46) 248.

68 UNSC Res 827 (1993) UN Doc S/RES/827; UNGA 'Report of the Secretary-General' (1993) UN Doc S/25704, para 29.

69 Nico Krisch, 'Introduction to Chapter VII: The General Framework' in Bruno Simma (ed), The charter of the United Nations: A commentary (3rd edn. Oxford University Press 2012) 1257.

70 Cf Pichon (n 46) 28.

71 UNSC Verbatim Record (31 March 2005) UN Doc S/PV.5158; see especially statements of Brazil, Benin, Tanzania, Greece, France, Argentina, Denmark.

72 Statement by Canadian Prime Minister (1 April 2005).

73 Only the Brazilian representative stated: "However, we express our strong reservation concerning paragraph 6 . We reiterate our conviction that initiatives aimed at establishing exemptions of certain categories of individuals from the jurisdiction of the International Criminal Court are not helpful to advancing the cause of justice and accountability and will not contribute to strengthening the role of the Court" Verbatim Record (26 February 
In order to understand the underlying challenge Resolution 1970 poses to the principle of universal jurisdiction, one must clarify the concept. ${ }^{74}$ The Princeton Project on Universal Jurisdiction defines universal jurisdiction as "criminal jurisdiction based solely on the nature of the crime, without regard to where the crime was committed, the nationality of the alleged or convicted perpetrator, the nationality of the victim, or any other connection to the state exercising such jurisdiction." ${ }^{75}$ It is generally accepted that the core international crimes included in the ICC Statute (ie crimes against humanity, genocide and war crimes) are of such nature. ${ }^{76}$ Since the exemption included in the Resolution provides that certain categories of nationals of States not party to the ICC "shall be subject to the exclusive jurisdiction of that State for all alleged acts or omissions arising out of or related to operations in the Libyan Arab Jamahiriya"77, any other States, including Libya the territorial state, therefore appear to be barred from exercising universal jurisdiction pursuant to this decision of the Security Council, which under Article 25 of the UN Charter is binding on all UN Member States and prevails over other conflicting international agreements (art 103 UN Charter). Accordingly, only the State of nationality shall have jurisdiction over their current or former officials or personnel. Clearly this provision was intended to shield US activity in Libya from ICC prosecution. However, what might have been overlooked is the fact that the SC resolution barrs any other State from exercising universal jurisdiction under certain circumstances. ${ }^{78}$ That such exemptions are in conflict with the spirit of the Rome Statute, is obvious when recalling its preamble stating "that it is the duty of every State to exercise its criminal jurisdiction over those responsible for international crimes" ${ }^{\text {" }}$

2011) UN Doc S/PV.6491, 7.

74 On the debate on the legality of universal jurisdiction, see eg: Arrest Warrant Case (Democratic Republic of the Congo v Belgium) (Merits) [2002] ICJ Rep 3, paras 49-52 (Joint Separate Opinion of Judges Higgins, Kooijmans and Buergenthal, ArrestWarrant Judgment; Dissenting Opinion of Judge Van denWyngaert, ArrestWarrant Judgment, paras 49-58; Separate Opinion of President Guillaume, Arrest Warrant Judgment, paras 13-16; Declaration of Judge Ranjeva, Arrest Warrant Judgment, para 8).

75 Principle 1 (1), Mary Robinson, The Princeton principles on universal jurisdiction (Program in Law and Public Affairs, Princeton University 2001) 28;

76 see eg: The American Law Institute, Restatement (Third) of the Foreign Relations Law of the United States (1987), $₫ 402$, comments c-g, $\$ 404$, comments a-b, $\$ 423$; for a recent discussion see eg: Maximo Langer, 'Universal Jurisdiction as Janus-Faced: The Dual Nature of the German International Criminal Code' (2013) 11(4) Journal of International Criminal Justice 737.

$77 \$ 6$ of Resolution 1970 (2011) [emphasis added].

78 Whether the SC has the power to do so is beyond the scope of this paper; For an interesting account or the concept of criminal jurisdiction in international and national law see eg. Alejandro Chehtman, 'Jurisdiction' in Markus Dubber and Tatjana H Höernle (eds), Oxford Handbook of Criminal Law (Oxford University Press forthcoming).

79 Preamble of the Rome Statute of the International Criminal Court. 
It must also be noted that the exemptions of $\$ 6$ deviates from the principle of criminal jurisdiction based on territoriality. Crimes under the ICC statute are permissable claims for (state) jurisdiction for the territorial state, ie Libya. ${ }^{80}$ Being one of the pillars of State sovereignty, criminal jurisdiction can only be waived under exceptional circumstances, for normally criminal jurisdiction over crimes committed within their boundaries is exercised by the state on whose territory they were committed. ${ }^{81}$

However, the conflicting claims of criminal jurisdiction ${ }^{82}$ (Libya on the principle of territoriality ${ }^{83}$ and universal jurisdiction vs. US on nationality princi$\mathrm{ple}^{84}$ ) appear to be ,regulated ' by the SC Resolution. While beyond the scope of this paper, it is an interesting question whether the SC actually has the power to disregard this principle. That such exceptional measures are justified in light of maintenance of international peace and security is very doubtful and further appears to delegitimizes the ICC's mandate in Libya.

\subsection{Challenges to the Principle of Equality of Individuals before the Law}

The exemption included in $\$ 6$ of resolutions 1593 and 1970 prescribe that nationals, current or former officials or personnel from a State outside the State concerned in the referral, which is not a party to the Rome Statute of the International Criminal Court, shall be subject to the exclusive jurisdiction of that State and are thus excluded from prosecution by the ICC. Such outright differentiation based solely on the nationality and their capacity as military personell of the person concerned seems hard to be justified and appears to be at odds with art 27, providing for the irrelevance of any official capacity. Another important element of this principle that is being violated here is that like situations shall be treated alike..$^{85}$ That some states' nationals are more equal than others ${ }^{86}$ is thus incompatible with the principle of equality before the law- a principle that is recognized as a fundamental principle of justice. ${ }^{87}$ Indeed, it is the very rationale

807 th Meeting of the Committee of the Whole, 'Summary Records' (19 June 1998) UN Doc. A/CONF.183/C.1/SR.7, 184; The principle of Universal Jurisdiction itself is not without controversy, particularly regarding its usage of the principle by the North against underdeveloped States in the South, see eg. Jallow (n 59) 279.

81 Mauro Politi and Giuseppe Nesi (eds), The Rome Statute of the International Criminal Court: A challenge to impunity (Ashgate 2001) XV.

82 There exists no extradition treaty between the US and Libya for example.

83 "The principle of territoriality basically entails that a state has the normative power to prescribe criminal prohibitions which are binding on every person who is, for whatever reason, on its territory." Chehtman (n 77) 5.

84 The nationality principle is generally recognized as a basis for jurisdiction over extra-territorial acts, cf James Crawford and Ian Brownlie, Brownlie's principles of public international law (8. ed. Oxford University Press 2012) 459. with further references.

85 Jallow (n 59) 278.

86 Cryer (n 9) 217.

87 Jallow (n 59) 278.

(C) Palacký University Olomouc, Czech Republic, 2014.

ISSN 1213-8770 (print), ISSN: 2464-6601 (online). 
of the establishment of the ICC that justice be administered equally, particularly that no one shall escape the rule of law (ie that there shall be no impunity for the most serious crimes of concern to the international community as a whole). ${ }^{88}$

It is not clear, however, whether this principle is de lege lata part of and applies to international criminal jurisdiction of the ICC as well. One has to be reminded that the principle of universality as such is not a concept of the Rome Statute. ${ }^{89}$ A proposal by the German and South Korean delegation ${ }^{90}$ at the conference in Rome to delegate universal jurisdiction ${ }^{91}$ to the Court was rejected. ${ }^{92}$ As a result, the ICC's jurisdiction is inherently unequal in its applicability. And considering the accepted practice of excluding criminal jurisdiction for military forces stationed abroad eg. in status of armed forces on foreign territory agreements $(\mathrm{SOFA})^{93}$, it appears to be rather doubtful that it attained status of customary international law.

Indeed, while definitely posing a challenge to the legitimacy of the International Criminal Court, inequality seems to be inherent in the Rome Statute itself. $^{94}$ As one commentator observed, „, $[\mathrm{t}]$ he Rome Statute is flawed in that it does not ensure equal justice, but it was the best possible compromise given what was politically feasible at the time it was negotiated. ${ }^{\text {"95 }}$

88 Fritsche (n 29) 117; see also Preamble paras 4 and 5.

89 H.-P. Kaul, 'International Criminal Court (ICC)', Max Planck encyclopedia of public international law : MPEPIL (2009) <www.mpepil.com> accessed 20 March 2014, 1ff.

90 7th Meeting of the Committee of the Whole, UN Doc. A/CONF.183/C.1/SR.7, 19 June 1998, Summary Records,

p. 184, paras. 50-51 (Germany); ibid., pp. 182-184, paras. 52-54 (Republic of Korea).

91 G. Werle \& F. Weßberger, Völkerstrafrecht, 2007, 183

92 See eg: A. Abass, 'The International Criminal Court and universal jurisdiction' (2006) 6(3) International criminal law review, 349, 349-385; H.-P. Kaul \& C. Kreß, 'Jurisdiction and cooperation in the Statute of the International Criminal Court: Principles and compromises' [1999] Yearbook of international humanitarian law; The US considered it a violation of Art 34 VCLT, see D. J. Scheffer, 'The United States and the International Criminal Court' (1999) American Journal of International Law,

93 UN Secretary-General 'Observance by UN Forces of International Humanitarian Law', (6 August 1999) UN Doc ST/SG- B/199913.

94 "The basic jurisdictional regime of the Court itself is uneven: the omission of universal jurisdiction was painful for some, the sacrifice of custodial jurisdiction in particular painful for many. Two individuals who have committed the same crime in the same place at the same time may be treated differently, one surrendered to the ICC and one not, solely on the basis of their different nationalities. Article 124 of the Rome Statute protects citizens of certain States Parties from prosecution for war crimes for seven years. Article 13 (b) and article 16 governing the role of the SC in relation to the ICC create further inequalities; those situations of special concern to the SC and inparticular its permanent members will be dealt with differently from other situations." Fritsche (n 29) 117.

95 ibid 118. 
It seems then even more paradox, however, that the one instrument with which the ICC could dispense equal justice for all, i.e. through SC referrals, itself poses challenges to this principle.

\subsection{Challenges to the Principle of Independence of the Court}

Judicial independence is universally accepted in international criminal law ${ }^{96}$ and guaranteed by art 40 of the Rome Statute. Further reiterating this principle, art 2 of the Relationship Agreement states that the court is an "independent permanent judicial institution".

The questions raised by resolution 1970 and 1593 is then whether the exemption of certain categories of nationals from the jurisdiction of the court constitutes an interference by the SC with the conduct of individual cases and thus being contrary to the principle of independence. It is important to note that the principle of independence binds the SC, since the Council would otherwise violate article 1(1) of the Charter. ${ }^{97}$

Independence is understood as containing both an individual and institutional guarantee. ${ }^{98}$ However, such guarantees do not cover differences of, or limitations to jurisdiction in cases of SC referrals, since such referrals are inherently selective. Therefore, none of the elements the „Burgh House Principles On The Independence Of The International Judiciary ${ }^{\text {“99 }}$ put forward to ensure judicial independence, are violated in this respect.

It must be concluded that the SC Resolutions 1593 and 1970 do not violate the independence of the court, since the Court's independence pertaining to acts under its jurisdiction remains untouched.

However, it must be criticized insofar as the exemption of certain categories of nationals further restricts the scope within which the Court can ,exercise' its independence. From the victim's perspective this is a rather technical argument responding to accusation of applying a double standard.

This is, de lege lata, a general feature of international law: of the few international courts that do posses compulsory jurisdiction, none have general competences.

96 See eg: Article 12 ICTY Statute, Article 13 ICTRStatute, Article 13 SCSL Statute, Article 9 SCL Statute.

97 Erika de Wet, The chapter VII powers of the United Nations Security Council (Hart Publishing 2004) 343.

98 See eg: Articles 7 and 26 of the Banjul Charter.

99 The Burgh House Principles On The Independence Of The International Judiciary, The Study Group of the International Law Association on the Practice and Procedure of International Courts and Tribunals, in association with the Project on International Courts and Tribunals (2004) <http://www.ucl.ac.uk/laws/cict/docs/burgh_final_21204.pdf>

\footnotetext{
(C) Palacký University Olomouc, Czech Republic, 2014. ISSN 1213-8770 (print), ISSN: 2464-6601 (online).
} 


\section{Conclusion}

Instead of strengthening important principles of justice, the SC sets dangerous precedents in undermining them. Considering the wider negative implications for the ICC's legitimacy, credibility, impartiality, and independence, any future use of exemptions must be avoided. What becomes apparent is the inherently difficult relationship between the UN Security Council and the International Criminal Court. While the link between a judicial organ and a political organ concerned with international security, could in theory contribute to peace and justice, we look at a rather discouraging record in reality. It appears that the inherent dichotomy lies at the heart of the current state of international criminal justice: prosecuting individual suspects to end impunity, yet receiving cases only when collective security demands it. ${ }^{100}$ The decisive criteria for the success of the International Criminal Court thus lies with the Security Council. Unfortunately, it appears that „[d]epending on how a case is generated, then, the ICC can be either an independent criminal court, prosecuting international criminality for its own sake, or a UN body prosecuting criminals as an instrument to advance the Council's security objectives. ${ }^{\text {" }} 01$

However, all of these legal problems outlined above could be easily remedied by ensuring universal ratification of the Rome Statute. In the words of UN SG Ban Ki-Moon: "only once the Rome Statute has been universally accepted can the Court be as effective as we would wish it to be, with a truly global reach. ${ }^{102}$ In the same vain his predecessor Secretary-General Kofi Annan, after the conclusion of the Rome Statute emphasized: „By establishing the International Criminal Court, the international community proved its determination to put an end to impunity for the perpetrators of egregious violations of human rights and humanitarian law, and thus to contribute to the prevention of such crimes. Only a permanent court with universal jurisdiction can finally lay to rest the charge that the international community is being selective or applying double standards in deciding which crimes to investigate and punish. ${ }^{103}$

Until then, it is high time for the SC to dispense its powers in the interest of the international community as a whole and contribute to the positive development of international criminal law.

100 G. P. Fletcher, 'The ICC -- Two Courts in One?' (2006) 4(3) Journal of International Criminal Justice, 428, 428-433

101 ibid.

102 Statement of the UN Secretary General (20 November 2013)<http://www.un.org/sg/statements/index.asp?nid=7295>

103 Massimo Egidi in Politi and Nesi (eds) (n 80). 